\title{
Image Analysis: Performance Gaps of Batik Craft in Yogyakarta, Indonesia
}

\author{
Hengky, S. H. \\ Director, Shine Institute \\ Associate Professor, Triguna, School of Economic's \\ E-mail: hengky_halim@yahoo.com.au
}

Received: Oct. 31, 2014 Accepted: November 18, 2014 Published: December 11, 2014

doi:10.5296/bms.v5i2.6766 URL: http://dx.doi.org/10.5296/bms.v5i2. 6766

\begin{abstract}
This research's aim is to explore performance gaps of attractiveness of the batik craft in Yogyakarta by using an image analysis, and at the same time, responding the expectation of Practitioners of the art and Philologist of University Gajah Mada. This quantitative research was conducted in Yogyakarta. The 360 respondents were collected by purposive, stratified sampling, and triangulation. The data was tabulated by the content analysis and focused on the image analysis. There is a small gap of the image analysis between the actual and the expectation of the tourists, which indicating that the expectation still a little bit over the actual. It means that the performance of batik craft can be further improved by innovating and adapting based on the market segmentation. Innovation and adaptation can be done as the batik craft fabric's market competition concept, which returning to nature and using natural dyes and strive to meet market demand, friendly price, and environmental friendly. However, it is the right time to develop a white wood fiber as a raw material, which made by Indonesian's batik craft fabric industry in addressing the raw material problem.
\end{abstract}

Keywords: Batik craft, Innovation, Competition, Raw material 


\section{Introduction}

Batik has now grown up globally. The recognition of batik as an intangible cultural heritage by the United Nations Educational, Scientific and Cultural Organization (UNESCO) in 2009, is one proof that batik revitalization movement also spread across 18 provinces in Indonesia, including Papua. Nowadays, with the intervention of the professional designer, batik craft being the object of targeting global marketing for all young people and as a way of dress and style (Berita, 2014).

Moreover, batik fabric sample was investigated through the testing process in a test lab and test escapes Indonesian National Standard (SNI). On 28 September 2009, UNESCO endorsed Batik Cultural Heritage for Humanity of the Oral and non-material (Masterpieces of the Oral and Intangible Heritage of Humanity), and the granting of its charter recently conducted October 2, 2009 (Berita, 2014).

As the evidence of efforts to further enhance the promotion of batik to the world, Indonesia held a World Batik Summit (WBS), which takes place September 28 to October 2, 2011, at the Jakarta Convention Center. The event involved 1,000 national and international delegates from various groups, such as producers, academics, marketing, practitioners, designers, crafters, collectors, and enthusiast batik (Berita, 2014; and Utami, 2014).

In terms of the economics achievement, the value of trade batik craft in 2006 reaching USD 240.1 million, and in 2010 increased to USD 323.1 million. Meanwhile, the value of exports in 2006 was US \$ 14.3 million and in 2010, reaching US \$ 22.3 million, with an increase of 56 percent. The amount of labor absorbed batik craft's industry reached 916783 people in 2010, and the number of consumer's batik recorded 72.86 million people. It's certainly good and can continue improving, as it would further enhance employment opportunity (Berita, 2014).

Yogyakarta has been named the World Batik City, by the World Crafts Council (World Craft Council / WCC), on the $50^{\text {th }}$ anniversary of the organization in Dongyang, Zhejiang Province, China, on October 18 to 23, 2014 (Utami, 2014). Traditional Indonesian batik craft as a masterpiece has become an integral part of Yogyakarta. In addition to having a high art and priceless history, and batik has been able to provide economic benefits for the community. Center of batik in Indonesia is concentrated in Yogyakarta. In terms of history and art, batik craftsmen Yogyakarta has a high economic value (Mahmud, 2014; and Utami, 2014).

A practitioner of the art and Philologist of University Gajah Mada, expecting the government now needs to make the next step after getting the label as well as the need for a study center of Yogyakarta batik, because many people do not know and understand about the batik. So there needs to be a study of the batik, while there are currently no study centers of batik in Yogyakarta (Mahmud, 2014). Over the decades, batik has become a breath and a source of livelihood for the people on the north coast of Central Java (Nurbiajanti \& Triana, 2014).

This research's aim is to explore performance gaps of attractiveness of the batik craft in 
Yogyakarta by using an image analysis, and at the same time, responding the expectation of Practitioners of the art and Philologist of University Gajah Mada (Mahmud, 2014). The background of choosing Yogyakarta because the World Crafts stated Yogyakarta has been the World Batik City (Utami, 2014).

\section{Literature Review}

Basically, all the batik craft's images processed using wavelet transform. Some support functions in the craft motifs on the shape and texture with any characteristic value generated through the process of wavelet decomposition, including the gain coefficient approximation. The image of batik craft fabrics includes: Motif; Color; Ornament; Decomposition pattern recognition; Edge Detection; Grayscale; Feature Extraction; and Texture (Rangkuti, Harjoko, \& Putro, 2014).

Motifs can serve as features / characteristics in identifying the origin of batik craft. Basically, the depiction of the batik is a process of matching the characteristics of image search with characteristics (Rangkuti et al., 2014; and Hiremath \& Pujari, 2007).

A motif batik craft is original textile designs are often inspired by the cultural and spiritual significance. The motif is also called a pattern, patterns or the overall decoration on batik craft. Despite the importance of culture and spirit, a motif classification decision based on the design motifs that are not widespread. Previous create a motif based texture classification methods have proven successful, but using over 700 attributes. It was shown that the number of attributes can be reduced to $2 \%$ without significantly by reducing the level of classification. This suggests that the reduction in accordance with the attributes and classifications Batik (Loke, 2009).

Overview characterization motif based on the description of appropriate design features designed to summarize the overall look of an image. The features described here to be useful for images that appeal to the public as well. Features batik is made to explain the overall appearance of the following colors, texture, complexity and periodicity. Most of the features used to describe the appearance of a single image area (Huiskes \& Pauwels, 2004).

The color motif is a powerful visual attributes in making the similarity between the image and perception, thus, often served as the main source of features in image retrieval systems (e.g. Flickner et al., 1995; Cox, Miller, Minka, \& Papathomas, 2000; and Swain \& Ballard, 1991). Many features have been described in the literature to characterize the color and spatial distributions. Also for color decoration design may play an important role in determining the relevance of the search, both with respect to the dominant impression and desire a very specific structure (Mojsilovic, Hu, \& Soljanin, 2002; and Pass, Zabih, \& Miller, 1996).

Ornament is made by drawing or painting as element motifs, which adorn the batik craft. Ornament consists: The principal ornament / ornaments primary; and the Complementary / charger midwife. Ornament is an essential element in the motif, is an image with a certain 
shape that is large enough or dominant in a pattern. This ornament is also called the principal ornament. Here are the ornaments of classic traditional staple, which is comprised of: Meru, Tree of Life, Plants, Garuda, Bird, Temple or boat or building, flames, dragons, animals and butterflies (Sakri, 2014; and Eko, Yuda, Arrie, Fitri, \& Nanik, 2014).

Decomposition pattern recognition (Daubechies), is a wavelet decomposition that takes detail on different scales: Horizontally; Vertically; and Diagonally. The decomposition pattern recognition is made on the basis of pattern recognition (Huiskes \& Pauwels, 2004).

Edge detection in the processing of an image is the boundary between an object and its background. Edges (Martin) are placed in an image that correspond to the object boundaries and edges are pixels where the brightness of the image. Edge detection is one of the most commonly used operations in the image analysis. An edge is defined by discontinuities in gray level values. Edges (Sharifi) define as the boundaries between the regions in the image, which helped with segmentation and object recognition. They can show, where the shadow falls pictures or other noticeable change in the intensity image. It describes the spatial differences in the drawings. These differences form the boundaries that enable the human visual system to distinguish between homogeneous colors regions in images. Similarly, the content-based image retrieval systems use low level edge in the higher level features extraction techniques, such as contour and texture analysis to distinguish between the excavation areas with pictures (Setiani \& Suyoto, 2010).

Grayscale is a standard scale, gray used to assess changes in color on the color fastness test. Standard scale, gray consists of 5 pairs of standard plates, gray and every pair shows the difference or contrast of colors corresponding to the value of the color fastness. Value scale, gray determines the degree of difference or contrast the color of the lower level to the highest of horizontal, vertical and diagonal (Kwartiningsih, Setyawardhani, Wiyatno, \& Triyono, 2009; and Huiskes \& Pauwels, 2004).

Feature Extraction, is that the performance of batik craft that has a color fastness to rubbing dry and wet, and washed (Kwartiningsih et al., 2009; and Huiskes \& Pauwels, 2004).

The texture of the original batik craft fabric has a fabric performance not stiff, easy to cling, and soft. This is due to the nature of the dye that is only attached to the outer layer of the fabric, and the fabric does not seep (Huiskes \& Pauwels, 2004). In this study, some of the traits or characteristics of a texture described as a distribution of values of gray intensity image showing the distribution of the intensity values of gray. While, the texture characteristics that have not been used as entropy is used to measure the intensity distribution. Contrast is the opposite of homogeneity, which is to measure the homogeneity of the intensity variations in the image, and the strength of the intensity in different image (Rangkuti et al., 2014).

However, the image analysis of batik craft's fabrics: Motif of a batik craft, original textile designs are often inspired by the cultural and spiritual significance (Loke, 2009); Color motif, a powerful visual attributes in making the similarity between the image and perception 
(Mojsilovic et al., 2002; and Pass et al., 1996); Ornament, drawing or painting, as an element motifs, which adorn the batik craft (Eko et al., 2014); Decomposition pattern recognition (Daubechies), wavelet decomposition that takes detail on four different scales; Edge detection, discontinuities in gray level values; Grayscale, wavelet decomposition detail level horizontal, vertical and diagonal (Setiani \& Suyoto, 2010); Feature extraction becomes available and correspondingly, there is large heterogeneity in the types of the features; and Texture, easy to fall, not rigid and its soft (Huiskes \& Pauwels, 2004).

\section{Methodology}

This quantitative research was conducted from January 2013 - August 2014 in Yogyakarta. The 360 respondents were collected by purposive, stratified sampling, and triangulation (Jenning, 2001). Questionnaires were distributed to international and national tourists, clothes expert, batik craft's experts, the batik craft's sellers, the batik craft industry, and regional institutions. The data was tabulated by the content analysis (Cohen, 1960) and this research focused on image analysis (Soille, 2003) based on the unique pattern of batik craft, which include: Motif (Loke, 2009), Color (Mojsilovic et al., 2002; and Pass et al., 1996); Ornament (Eko et al., 2014), Decomposition pattern, Edge detection, Grayscale (Setiani \& Suyoto, 2010), Feature Extraction, and Texture (Huiskes \& Pauwels, 2004). The content analysis of image analysis (Cohen, 1960): Exploratory analysis of image analysis; Posting each parameter of image analysis; Frequency of image analysis; Frequency counted of image analysis; and image analysis discussions.

\section{Result and Discussion}

\subsection{The Actual Image Analysis of the Batik Craft}

According to the tabulation of actual image analysis (Table 1), this study found that the tourists buy the batik craft because the motif of batik craft is the most attractive. While, a color motif of batik craft is more attractive, the ornament of batik craft is attractive, and texture of batik craft is quite attractive.

Batik craft is not only the visualization of images, but also it contains a spiritual visualization. In the craft fabrics, there is a religious, mystical, energy, and that is not any at other textiles. In the history, the process of batik-making begins with rituals, such as fasting, because there is no hope or prayer of the meaning of a piece of cloth, such as "Batik Wahkyu Tumurun", "Sido Drajat", and "Sido Mukti". Ancestors used when batik, also directly dealing with nature, and make direct contact with the flora and fauna.

Table 1. The result tabulation of actual image analysis of the batik craft fabric's Yogyakarta

\begin{tabular}{|l|c|c|}
\hline The Actual images of batik craft fabrics' Yogyakarta & Value & $\%$ Freq \\
\hline Motif batik craft, designs - cultural and spiritual significance & 41 & 0.1496 \\
\hline Color motif, a powerful visual attributes - image - perception & 39 & 0.1423 \\
\hline Ornament of batik craft & 36 & 0.1314 \\
\hline
\end{tabular}




\begin{tabular}{|l|c|c|}
\hline Decomposition pattern recognition & 33 & 0.1204 \\
\hline Edge detection - boundaries between the regions in the image & 31 & 0.1131 \\
\hline Grayscale - assess changes in color on the color fastness test & 30 & 0.1095 \\
\hline Feature extraction - a color fastness & 29 & 0.1058 \\
\hline Texture - easy to fall, not rigid and its soft & 35 & 0.1277 \\
\hline Kappa coefficient $=\mathrm{K}=0.7611$ & \multicolumn{2}{|l}{} \\
\hline
\end{tabular}

Notes: This table displays the results of our content analysis. The period under our analysis is from January 2013 - August 2014, Significant at K > 0.6000

Etymologically, the word of batik craft derived from the Javanese "Amba", meaning to write and "Nitik", where refers to the pattern-making technique, and applied on top of the fabric. The trick, using a canting or cap and dyeing batik craft using the color barrier material shades of "Tapioka" (wax), so that resist the entry of dye. In English, this technique is known as wax-resist dyeing. Since hundreds of years ago, the people of this country are already familiar with the traditional fabrics. Obviously, batik is not new to the people of Indonesia. In the past, batik has been just a symbol of cultural heritage, so it is only used for special occasions, such as weddings and other formal events.

The motif of batik craft from Yogyakarta consists of: Slopes, hills, diagonal lines, fried expressed as geometric designs often based on circular roses, stars or other small form symmetrical overall patterning on the fabric; and the Water droplets and pictographic designs that complement, most interpretations of mountains, or mountain symbol, the "Wayang puppets". Parang grouped in categories slope. Motif symbolizes authority, and another motif Slope is "Riris Udan", which symbolizes good luck. Moreover, in the category of cooking, rural areas have the most classical motif, "Truntum". In particular, craft's motif expresses a tale. In short, motif Batik is original textile designs are often inspired by the cultural and spiritual significance (Prathivi, 2014).

Yogyakarta batik craft generally have the latest design and style of choice with a very beautiful modern batik motif, color, motif with powerful visual attributes, and the color type is quite interesting. Based on the material for this dress, which made of "Cotton Primisima" or often called "Primis" high quality cotton and has many features: The material is very comfortable to wear, even if the weather is hot and sultry outside less friendly; The color motif is quite durable and not easily fade if washed, despite repeated laundering; and Many of the latest selection of batik crafts motifs that can be selected according to taste a batik craft clothing and quality is excellent.

The color and motif are also quite important that fit in wearing batik later. In choosing the colors and motifs of batik craft, can be chosen in accordance with the character wearing it. The selection of motifs and colors are also adjusted to the posture itself. For those with a fat body posture wearing small motifs in order to attract and a slim body posture was recommended to choose a big motif. To be more elegant also adjusts skin tones to wear. 
Ornament of the batik craft (Sakri, 2013) of classic traditional staple which is comprised of: Meru, Tree of Life, Plants, Garuda, Bird, Temple or boat or building, flames, dragons, animals and butterflies. The brief description of the ornament of the batik craft: Firstly, "Meru" as a mountain like shape, sometimes depicted with a series of three mountains with a mountain in the middle of a mountain peak. Secondly, Tree of life as a tree of heaven is also as a form of imaginary tree that is mighty and powerful, and is a symbol of life. This tree is described as stems, branches, buds, leaves, roots or "Sobrah Tunjang". This tree is found in almost all regions in Indonesia with many variations. Thirdly, Plants described as one part such as a flower, a bunch of leaves or buds, or a series of flowers and leaves. Plants sometimes described as scrolls, that creeper curved shape. In classical ornament motif plays a role as a principal ornament or ornament filler. Fourthly, Garuda as an imaginary creature that the mighty and powerful, while the vehicle of Lord Vishnu is also described as Garuda. Fifthly, there are three kinds of birds in batik ornaments as a peacock, phoenix, and a strange bird or bird's delusion. Bird ornaments are also used as filler ornaments besides the principal ornament.

Moreover, sixth, the buildings as the ornaments that depict parts of the building consist of the base and the floor or roof. Seventh, ornaments flames depicted in two different forms, namely as a row of flames as decorative edge or boundary, and a row of elongated flame tip. In the old days, the fire symbolizes the power of magic that could affect human personality, which when mastered can be brave and a hero. Eighth, the dragon ornament as an imaginary creature in the form of a large snake that has incredible power and magic. As depicted in the form of a dragon ornament like a giant head with a crown sometimes winged and legs. The ninth, the animals are often used as ornaments are cattle, deer, elephants, lions or tigers, and uniquely illustrated as an example elephants has wings or tail flower. Finally, butterflies, this ornament are usually depicted with outstretched wings from above.

Furthermore, according to Table 3 above, the texture of the batik craft of Yogyakarta is quite attractive, the fabric will be easy to cling, and not rigid and has a soft texture. This is due to the nature of the dye that is only attached to the outer layer of the fabric, does not permeate into the fabric of batik craft.

Nevertheless, the craft texture is quite attractive to discuss, because the batik fabric texture quality cannot be separated from the manufacturing process, and the process of manufacture must pass 12 steps (Aur, 2013). Firstly, creating the motif based on certain ornament on the surface of a craft. Secondly, moving ornament from paper to fabric pattern. Thirdly, attaching the wax and canting according to the motif. Fourthly, adding complementary motifs on main ornaments. Fifthly, coloring the certain parts of batik craft by using a brush. Sixth, closing the already dab the night. Seventh, staining a batik craft thoroughly to the horizontally and vertically. Eighth, removing wax by soaking batik craft in boiling water. Ninth, "Ngerentesi", we're giving "Cecek" or points on "Klowongan". Tenth, closing the craft ornament with a wax (candle). Eleventh, maintaining batik fabric surfaces with "Warga Sogan". The twelfth, the removal of the night (candle) by soaking a craft in boiling water. 
Batik craft is made by hand from start to finish, and need a time longer than made the write batik crafts print. Even more complicated is an incised motif which is the main ornaments on the base material and fills the ornaments (details of the main Ornament). It takes persistence and thoroughness when the main incised the ornament and its fill the main by using "Canting writes" or Batik's pen. While, the time of making batik print is faster. An ornament made in an incision in the base material using a canting seal. Filling the main ornament also use a canting seal. The craft's motifs do not emphasize details such as batik print.

\subsection{The Expectation Image Analysis of the Batik Craft}

In terms of image analysis, result tabulation of expectation image analysis (Table 2) of batik craft of Yogyakarta, indicating that color motif is the main point and most attractive. While, motif batik is more attractive, the ornament of batik is attractive, and texture is quite attractive.

Table 2. The tabulation of expectation image analysis of a batik craft fabric's Yogyakarta

\begin{tabular}{|l|c|c|}
\hline The Expectation of images of batik craft fabrics' Yogyakarta & Value & $\%$ Freq \\
\hline Motif batik craft, designs - cultural and spiritual significance & 43 & 0.1468 \\
\hline Color motif, a powerful visual attributes - image - perception & 44 & 0.1502 \\
\hline Ornament of batik craft & 41 & 0.1399 \\
\hline Decomposition pattern recognition & 39 & 0.1331 \\
\hline Edge detection - boundaries between the regions in the image & 30 & 0.1024 \\
\hline Grayscale - assess changes in color on the color fastness test & 28 & 0.0956 \\
\hline Feature extraction - a color fastness & 32 & 0.1088 \\
\hline Texture - easy to fall, not rigid and its soft & 37 & 0.1263 \\
\hline Kappa Coefficient $=$ K $=0.8167$ & & \\
\hline
\end{tabular}

Notes: This table displays the results of our content analysis. The period under our analysis is from January 2013 - August 2014, Significant at K > 0.6000

Batik craft fabrics preserved for generations are now becoming one of the batik craft in Indonesia. Not only because of the fineness, but also retain the traditional motif. Previously, a dyeing batik craft is only known as "Sogan" (brown color) and "Wedel" (blue-black).

Whatever the motives of batik craft, the second color of the final product of batik craft have been improved by the producers, and they are now beginning to modify their products with a variety of motives, including contemporary motifs, as already being produced today, batik craft patterned "Pesley".

Even to make the batik craft motif, the producers fulfill consumer demand, whether from a number of agencies and schools that orders is according to their specifics. Creating the batik craft motif is similar with made the ornament of the electrical installations by an electrical engineer. In addition, the producer of batik craft is also producing "Batik Jarik" (a long cloth) and the needs of fashion (clothing), the producer of batik. Batik crafts made for other media 
such as wood (wooden masks) and skin (wall hangings).

\subsection{Gaps Analysis of Batik Craft}

The result of gaps of an image analysis of the actual and the expectation of the tourists (Table $3)$, indicating that the expectation still a little bit over the actual $(K=0.0528)$. It means that the performance of batik craft could be further improved, with an enhancing tourist image of craft by innovating and adapting to the market segmentation.

Innovation and market adaptation can be done with the market competition of batik craft fabric by the concept of a returning to nature by using natural dyes and strive to meet green market demand. On the other hand, there is an urgent matter to continue producing batik craft with a friendly price and do not damage the environment. Sooner or later, there will be a change in the market driven, especially when young skilled labor is reduced, because they are looking for another job that more interesting and offer them more rewarding.

Table 3. Gaps analysis of batik craft fabric's Yogyakarta

\begin{tabular}{|l|c|c|c|}
\hline The gap images of batik craft fabrics'Yogyakarta & Actual & Expect & Gaps \\
\hline Motif batik craft, designs - cultural and spiritual significance & 0.1496 & 0.1468 & 0.0029 \\
\hline Color motif, a powerful visual attributes - image - perception & 0.1423 & 0.1502 & 0.0078 \\
\hline Ornament of batik craft & 0.1314 & 0.1399 & 0.0085 \\
\hline Decomposition pattern recognition & 0.1204 & 0.1331 & 0.0127 \\
\hline Edge detection - boundaries between the regions in the image & 0.1131 & 0.1024 & 0.0107 \\
\hline Grayscale - assess changes in color on the color fastness test & 0.1095 & 0.0956 & 0.0139 \\
\hline Feature extraction - a color fastness & 0.1058 & 0.1088 & 0.0030 \\
\hline Texture - easy to fall, not rigid and its soft & 0.1277 & 0.1263 & 0.0015 \\
\hline Total & 0.7611 & 0.8167 & 0.0556 \\
\hline
\end{tabular}

Notes: This table displays the results of our content analysis. The period under our analysis is from January 2013 - August 2014

In the meantime, the rapid development of technology will also be applied in the batik craft's industry as a natural batik craft, batik printing, batik and textile printing and dyeing as well. In the future, the innovation of making batik craft will occur and less predictable. However, the development of batik craft will grow in a sustainable manner, as long as there are young people who have a passion for preserving the nation's heritage.

Nevertheless, there is a supply chain constraint of craft raw materials, such as cloth, which is still imported, start being addressed by continuing to innovate. Today, there is an effort on developing fabric of eucalyptus wood fiber, to be processed into raw material of batik. The innovation of the production of the batik craft is not only in the form of batik techniques, but also on the innovation of raw material.

Raw material of batik craft can actually be made from breadfruit bast fibers, which made of breadfruit trees. It has been tried and developed some useful things, while there are a lot of 
breadfruit forests everywhere in Indonesia, and then there is no reason for the producer difficult in obtaining raw materials of crafts.

One of the best raw material of a batik craft (Batikbolags, 2012) is "Mori Primissima", is the most delicate Mori fabric and is usually used for the type of batik is batik is very smooth. The other raw material of a batik craft is "Mori Prima", is having a second quality after "Mori Primissima". While, the common raw material of a batik craft is cotton fabric is a fabric that is commonly used for batik.

Regardless of the raw material, batik craft's sales will continue to increase as more Indonesian people using it as a daily wear (Gundala, 2010). Now, batik is not only used for a daily wear, but also for a variety of household, interior, fashion, product ingredients and purposes of the craft for casual wear, and even has been used in the shoe industry. And each area, it has a character of its own peculiarities. Batik craft's pattern has become an industry. Batik is no longer a commodity, but has used a brand that is seriously being developed.

As a consequence, Indonesian batik craft is now not only sought after in the domestic market. The work of fashion designers has also managed to penetrate foreign markets. Batik craft's industry has spread in almost all regions of Indonesia, and its presence in the centers of cities and rural industries can create jobs is quite large. The main area of batik craft's industries scattered in various provinces, including Central Java, Yogyakarta, West Java, East Java, Jakarta, Bali, Bengkulu, and Jambi.

As part of the World Batik Summit 2011, one thing needs to be emphasized that the batik craft is not only the heritage of the culture, but it can become the economic powerhouse as well. Batik in eye wears Ministry of Commerce has the big opportunity as one of the icons for the branding of Indonesian nation as well as strengthening the domestic market. Here, the role of batik craft is very strategic.

The government outlining the craft program in the Blueprint "Preservation and Development of National Batik 2012-2015", who explains that with batik, Indonesia can show itself as a country that has integrity, commitment, and high seriousness in preserving and developing the culture of Indonesian batik. Furthermore, the use of batik should be encouraged, because the batik has high economic values to continuously campaign and promoted-both domestically and abroad.

Batik, in other words, become an integral part of the "Movement 100 percent Love Indonesia". Former South African President, Nelson Mandela proudly wears a batik shirt on at various occasions. Among other things, when his first speech as President of South Africa (May 1994), the official ceremony of FIFA in Zurich, Switzerland, to receive a relay host the World Cup (early June 2006), the launch of the Association of Former World Leaders, The Elders (July 2007), and various other formal events.

It turns out that not only Mandela proudly uses batik, but there is also a mother of US President Barrack Obama, Ann Durham. As a token of appreciation, the Indonesian 
government with other parties Indonesian organizing the collection Exhibition of Batik of Mother Ann Dunham in the Walton Room, Drake Hotel, Chicago, from 17-20 May 2009. A total of 22 traditional Indonesian batik legacy of the late Mrs. Ann Dunham exhibited there. All this shows the high competitiveness of batik craft products.

\section{Conclusions}

According to image analysis, this study found that batik craft in Indonesia attracting the tourist. There is a small gap of the image analysis between the actual and the expectation of the tourists, which indicating that the expectation still a little bit over the actual. It means that the performance of batik craft can be further improved by innovating and adapting the market segmentation.

Innovation and market adaptation can be done as the market competition concept of batik craft fabric, by returning to nature, and using natural dyes and strives to meet market demand as friendly price and environmental friendly. The future innovation of making batik craft that occurs less predictable, and there is a constraint of raw materials, such as cloth, which is still imported, and it's being addressed by continuing to innovate.

The limitation of this study is the reference, time and funding. Therefore, further research about batik craft still can be conducted, especially about the innovation of raw material and other aspect, which include in processing and marketing aspects.

\section{Implications}

In terms of raw material, there is a supply chain constraint of craft raw materials, such as cloth, which is still imported, start being addressed by continuing to innovate. Today, there is an effort on producing of fabric from eucalyptus wood fiber, to be processed into raw material of batik. The innovation of the production of the batik craft is not only in the form of batik techniques, but also on the innovation of raw material.

Raw material of batik craft is also can actually be made from breadfruit bast fibers. It has been tried and produced some useful things, while there are a lot of breadfruit forests everywhere in Indonesia, and then there is no reason for the producer difficult in obtaining raw materials of crafts.

Moreover, it is the right time to develop a white wood fiber as a raw material of Indonesia's batik craft fabric (Hidayat, 2014), as well as Cotton batik dye is still imported. Currently Indonesia's batik craft expert is developing a white wood fiber that they get it from Austria, to substitute for cotton because cotton is not suitable to be planted in Indonesia. This is actually a potential upstream product on addressing the raw material problem (Setiawan, 2014).

\section{References}

Aur, A. (2014). Traveling while Studying Batik in Pekalongan Batik Museum, Wisata Kompasiana. http://wisata.kompasiana.com/jalan-jalan/2013/10/16/berwisata-sambil-belajar-membatik-di- 
museum-batik-pekalongan-600971.html

Batikbolags (2012). Type - the type of fabric in Batik, BatikbolaGS.com. Retrieved from http://www.batikbolags.com/jenis-jenis-kain-dalam-batik/

Berita, D. (2014). Batik as a Motor Drive Economy, Directorate General of Domestic Trade. Retrieved from http://ditjenpdn.kemendag.go.id/WEB/index.php/public/information/articles-detail/berita/38

Cohen, J. (1960). A Coefficient of Agreement for Nominal Scales. Educational and Psychological, 20, 37-46. http://dx.doi.org/10.1177/001316446002000104

Cox, I., Miller, M., Minka, T., \& Papathomas, T. (2000). The Bayesian image retrieval system, PicHunter: Theory, implementation, and psychophysical experiments. IEEE Trans. Image Processing, 9 (1), 20-37. http://dx.doi.org/10.1109/83.817596

Eko. M. A., Yuda, M., Arrie, K., Fitri, B., \& Nanik, S. (2014). Texture feature extraction using co-occurrence matrices of sub-band image for batik image classification. 2nd IEEE's International Conference, 249-254. http://dx.doi.org/10.1109/ICoICT.2014.6914074

Flickner, M., Sawhney, H., Niblack, W., Ashley, J., Huang, Q., Dom, B., Gorkani, M., Hafner, J., Lee, D., Petkovic, D., Steele, D., \& Yanker, P. (1995). Query by image and video content: The QBIC System. IEEE Computer, 28 (9), 23-32. http://dx.doi.org/10.1109/2.410146

Gundala, R. R. (2010). Retail Store Image: A Study of The Cyprus Clothing Industry. International Journal of Management and Marketing Research, 3 (3), 67-81. Retrieved from http://ssrn.com/abstract=1880203

Hidayat, W. (2014). Fiber Raw Materials Breadfruit can be alternative Fabric, Radar Pekalongan. Retrieved from http://www.radarpekalonganonline.com/44879/serat-sukun-bisa-untuk-bahan-baku-kain

Hiremath, P. S., \& Pujari, J. (2007). Content Based Image Retrieval based on Color, Texture and Shape features using Image and its complement. IEEE Computer Society, 780-784. http://doi.ieeecomputersociety.org/10.1109/ADCOM.2007.21

Huiskes, M. J., \& Pauwels, R. J. (2004). Indexing, Learning and Content-based Retrieval for Special Purpose Image Databases, Centrum voor Wiskunde en Informatica. Retrieved From http://oai.cwi.nl/oai/asset/11010/11010D.pdf

Jenning, G. (2001). Tourism Research, John Willey \& Sons Australia, Ltd., 136-152

Kwartiningsih, E., Setyawardhani, D. A., Wiyatno, A., \& Triyono, A. (2009). Substances of Natural Dyes, Textile, Leather Mangosteen. EKUILIBRIUM, 8 (1), 41 -47. Retrieved from http://core.kmi.open.ac.uk/download/pdf/12345616.pdf

Loke, K. (2009). Efficient textile recognition via decomposition of co-occurrence matrices, IEEE International Conference. http://dx.doi.org/10.1109/ICSIPA.2009.5478606 
Mahmud, F. (2014). Achieves World Batik City, Yogya must have a study about batik, Liputan6. Retrieved from http://lifestyle.liputan6.com/read/2122848/raih-kota-batik-dunia-yogya-harus-punya-studi-ten tang-batik

Mojsilovic, A., Hu, J., \& Soljanin, E. (2002). Extraction of perceptually important colors and similarity measurement for image matching, retrieval, and analysis, IEEE Trans. On Image Processing, 11 (11), 1238-1248. http://dx.doi.org/10.1109/TIP.2002.804260

Nurbiajanti, S., \& Triana, L. (2014). From Pekalongan Batik Global, Travel Kompas. Retrieved from http://travel.kompas.com/read/2013/07/17/1758369/Dari.Batik.Pekalongan.Mendunia

Pass, G., Zabih, R., \& Miller, J. (1996). Comparing images using color coherence vectors, Fourth ACM Conference on Multimedia, 65-73. Retrieved from http://dl.acm.org/citation.cfm?id=244148

Prathivi, N. (2014). Decoding batik, The Jakarta Post. Retrieved from http://www.thejakartapost.com/news/2014/03/08/decoding-batik.html

Rangkuti, A. H., Harjoko, A., \& Putro, A. E. (2014). Content Based Batik Image Retrieval. Journal of Computer, 10 (6), 925-934. http://dx.doi.org/10.3844/jcssp.2014.925.934

Sakri, G. (2013). Batik: Motif \& Ornamen, Desain Komunikasi Visual. Retrieved from https://ap304.wordpress.com/2013/05/21/batik-motif-ornamen/

Setiani, E. D., \& Suyoto. (2010). New Edge Detection Method Using Elisabeth Method: Case Study Javanese Batiks. Jurnal Buana Informatika, 1 (1), 47-56. Retrieved from http://ojs.uajy.ac.id/index.php/jbi/article/view/289/370

Setiawan, H. (2014). Still Imported Raw Materials, Business Fluctuations Batik Prone US Dollars, Detik Finance. Retrieved from http://finance.detik.com/read/2014/03/06/121714/2517319/1036/bahan-baku-masih-impor-bis nis-batik-rawan-fluktuasi-dolar-as

Soille, P. (2003). Morphological Image Analysis: Principles and Applications, Springer-Verlag New York. USA. Retrieved from http://dl.acm.org/citation.cfm?id=773286\&preflayout=flat

Swain, M., \& Ballard, D. (1991). Color indexing, International Journal of Computer Vision, 7 (1), 11-32. http://dx.doi.org/10.1007/BF00130487

Utami, R. (2014). Yogyakarta has been named as the World Batik City, Antaranews.com. Retrieved from http://www.antaranews.com/berita/459519/yogyakarta-dinobatkan-sebagai-kota-batik-dunia 


\section{Copyright Disclaimer}

Copyright for this article is retained by the author(s).

This is an open-access article distributed under the terms and conditions of the Creative Commons Attribution license (http://creativecommons.org/licenses/by/3.0/). 